\title{
Psychodrama technique in enhancing communications skills among Special Education Integration Program (SEIP) students in Malaysia: a case study
}

\author{
Siti Khadijah Hashim ${ }^{1}$, Abu Yazid Abu Bakar ${ }^{2}$ \\ ${ }^{12}$ Universiti Kebangsaan Malaysia, Malaysia
}

\begin{tabular}{l}
\hline \hline Article Info \\
\hline Article history: \\
Received Dec $11^{\text {th }}, 2019$ \\
Revised Jan $17^{\text {th }}, 2020$ \\
Accepted Feb $13^{\text {th }}, 2020$ \\
\hline
\end{tabular}

\section{Keyword:}

Communication skill psychodrama technique special education students

\begin{abstract}
This study aimed to determine the effectiveness of psychodrama technique in enhancing social interaction among Special Education Integration Program (SEIP) students in Malaysia. The objectives of the study were to train SEIP students to communicate well through psychodrama, to increase selfconfidence when communicating and to expose students to self-management through psychodrama. The study was conducted via group session on a psychoeducational program involving 13 students with different learning disabilities at Sekolah Kebangsaan Taman Seri Mawar, Negeri Sembilan. The results show that SEIP students knew the knowledge on how to manage themselves but still need to be improved in terms of communication skills and social interaction in groups.
\end{abstract}

\section{Corresponding Author:}

Abu Yazid Abu Bakar,

Universiti Kebangsaan Malaysia, Malaysia

Email: yazid3338@ukm.edu.my

\section{Introduction}

The Malaysian Special Education Integration Program (SEIP) is a school-based program that helps students with learning disabilities to get the same type of education as other students. Education for SEIP students is slightly different and teaching these children is not an easy task. It requires different technique and teaching medium. According to Borhannudin and Wan Nomi (2018), special education children are different from normal children in terms of mental, sensory, neurological, muscle, physical, social, emotional, communication, and other disabilities. Therefore, it is very important for this group to be focused on so that they can live a normal life like everyone else.

Communication skills are very important in life. Therefore, it is very important for SEIP students to be exposed to communication skills as well as to help students to improve their social interaction skills. One of the most effective techniques for training students to be confident in communication is psychodrama techniques. These techniques help students to express their emotions and expressions through acting. Through psychodrama, this study can help counsellor to gain information about the level of knowledge of students in the area of self-management. 
A study conducted by Peter and Lidija (2012) states that psychodrama can change an individual old behaviour to new behaviours and improve existing behaviours. Through psychodrama, it gives students knowledge about the subject matter and indirectly what they have watched in psychodrama is usually what they have to apply in everyday life.

According to a study by Chae and Kim (2017) on Korean students from a university in Korea showed that psychodrama is an effective technique for interpersonal relationship and it indirectly helps the students to reduce stress and anxiety. In fact, the study also suggests that it helps students' mental development and improve their general knowledge

This study aimed to determine the effectiveness of psychodrama techniques in assisting SEIP students in the aspects of communication and social interaction between groups. It focuses on student self-management in everyday life. Educating SEIP students is not an easy task. Thus, various techniques and methods need to be developed to teach SEIP lessons. Providing the perfect education for these special students is challenging and require high responsibilities. These students need special attention throughout their lives (Kamashi, 2016).

\section{Method}

The study conducted was a qualitative study in which the data was collected through interviews and observations conducted during the group session. A total of 13 students were involved in this study at the ages between 7 and 14 years old. Students in the group were selected using the intended sampling method. Students were divided into three groups and each group is assisted by a group leader. Each group was given a task where they have to act out based on their chosen character and they have to show their daily routine. They were given props such as cutlery, mattress, handkerchief, prayer mat and materials related to daily life routine. They have to act out and use the props given based on suitable situation. Each group were given 20 minutes to discuss and they have to act out. They were observed based from their knowledge on daily routine and how they play their role. The limitation of this study is duration of time. This study should be conducted in few more sessions.

Table 1 Daily Life Routine through Psychodrama Technique

\begin{tabular}{|c|c|c|}
\hline Group & Routine & Results \\
\hline 1 & Morning & $\begin{array}{l}\text { Able to act out their daily routine since they woke } \\
\text { up but have difficulty in communicating }\end{array}$ \\
\hline 2 & Afternoon & $\begin{array}{l}\text { Able to show their activities after they went back } \\
\text { from school but have difficulty in communicating }\end{array}$ \\
\hline 3 & Evening & $\begin{array}{l}\text { Able to show at home routine with their family } \\
\text { members but have difficulty in communicating }\end{array}$ \\
\hline
\end{tabular}

\section{Results and Discussions}

Through psychodrama, it exposes individuals to the use of verbal and non-verbal communication such as facial expression, voice volume and body position (Samira, 2006). Psychodrama is one of the fun teaching techniques because it is more spontaneous where students are free to share their ideas and imagination.

Social problems often occur due to the lack of communication skills as well as lower self-esteem of the individual. Therefore, this problem needs to be addressed from the beginning especially for SEIP students. Usually, students with special needs will be bullied and received negative perceptions from society. Therefore, they need to be exposed to normal life and to build their self-confidence in facing society. Psychodrama also indirectly helps the teacher or counsellor to know student's emotions and self-thoughts.

Overall, psychodrama session on SEIP students helps them to understand the importance of selfmanagement in their daily life. They get information about proper self-management routines. In fact, they can learn the right communication skills during discussions with their group members. Students can interact socially with other members of the group. In addition, psychodrama also helps build students' confidence when communicating.

Psychodrama session helps students to express emotions through spontaneous and fun acting. Exposure to real life situation should be implemented on psychodrama session. Therefore, some improvements need to be 
made to assist SEIP students by conducting follow-up sessions with different psychodrama activities and techniques.

The one-hour psychodrama session was conducted to determine the effectiveness of psychodrama on student communication skills as well as students' level of confidence when interacting with group members. The results of the study showed that the SEIP students of Sekolah Kebangsaan Taman Seri Mawar had basic skills in self-management concepts. However, students' communication skills still need to be improved and they need guidance.

\section{Conclusions}

Psychodrama techniques help students to express their emotions as well as to help students develop selfconfidence and communication skills. Moreover, psychodrama techniques also help students to apply what they have learnt in their real life situation. The results of psychodrama also help students to learn about selfefficacy as well as to increase their knowledge of self-management. However, SEIP students need to be guided on how to communicate effectively.

\section{References}

Borhannudin Abdullah \& Wan Nomi Wan Omar. (2018). The Importance of Early Intervention Programs on the Development of Special Needs Individual. International Journal of Academic Research in Business \& Social Sciences, 8(12): 510-516.

Ina ter Avest. (2017). "I experienced freedom within the frame of my own narrative" : The contribution of psychodrama techniques to experiential learning in teacher training. Springerlink.com, 71-87.

Soo Eun Chae \& Soo Jin Kim. (2017). Group psychodrama for Korean college students. Journal of college students psychotherapy, 59-70.

Samira Munir. (2006). The Use of Psychodrama Techniques for Students with Asperger's Disorder. 1-38.

S. Kamashi, G. Mala, \& N. Jaya. (2016). Effectiveness of psychodrama on siblings' support among siblings' of mentally challenged children. Asian Pacific Journal of Research, (pp. 58-62). India.

Peter Haworth \& Lidija Vasiljevic. (2012). Psychodrama and action methods in education. 113-128. 